\title{
29. Swedes in French: Cultural Transfer from Periphery to Literary Metropolis
}

Andreas Hedberg

Literature, Uppsala University

There is a long tradition of cultural exchange between Sweden and France. ${ }^{\mathrm{T}}$ Typically, this exchange has been dominated by cultural phenomena moving northward, from Paris to Stockholm. However, in the context of understanding the relationship between the vernacular and the cosmopolitan, between the dominated and the dominating, one should not neglect the cultural products that have traveled the opposite route. Translations into French have played an important role for the continued mediation of Swedish fiction to the literary world. For instance, France was among the first major foreign markets for Stieg Larsson's now world-famous crime novels. ${ }^{2}$ But there are several older examples. A French translation of the Swedish Nobel prize laureate Selma Lagerlöf's debut novel Gösta Berlings saga (I89I) was published as early as I 904 and marked the beginning of a half-century-long heyday for

I Cf. e.g. Une amitié millénaire: Les relations entre la France et la Suède à travers les ages, L'historie dans l'actualité, edited by Marianne and JeanFrançois Battail (Paris: Beauchesne, I993).

2 Sylvain Briens and Martin Kylhammar, Poétocratie. Les écrivains à l'avant-garde du modèle suédois (Paris: Ithaque, 2016), 357.

How to cite this book chapter:

Hedberg, Andreas. "Swedes in French: Cultural Transfer from Periphery to Literary Metropolis”. In World Literatures: Exploring the CosmopolitanVernacular Exchange, edited by Stefan Helgesson, Annika Mörte Alling, Yvonne Lindqvist, and Helena Wulff, 355-368. Stockholm: Stockholm University Press, 20I8. DOI: https://doi.org/IO.I6993/bat.ac. License: CC-BY. 
Lagerlöf in France. ${ }^{3}$ The French were also quick to discover two other Swedish Nobel prize laureates, Eyvind Johnson (published in French as early as 1927) ${ }^{4}$ and Harry Martinson (eight works translated since 1938 , not counting single poems published in anthologies or magazines). Furthermore, the Swedish existentialist writer Stig Dagerman was published by the prestigious Éditions Gallimard in the I950s, and has been praised by French Nobel prize laureates Jean-Marie Le Clézio and Patrick Modiano. ${ }^{5}$

The research project "From Periphery to Center. Swedish Literature on the French Book Market 1945-2013" addresses the question of how a peripheral (or semi-peripheral) literature is established on a central literary field, with a special focus on the role of literary mediators in this venture. Drawing on bibliographical data ${ }^{6}$ and using qualitative methods including interviews, the study investigates how translators, publishers and mediators shape the transmission process. The objective of the study is to analyse the logics at work in the meeting of two literary systems and to make a general contribution to the understanding of literary circulation as such. In this introductory essay, the project's theoretical framework will be established through a discussion of

3 Guy de Faramond, Svea \& Marianne: Les relations franco-suédoises, une fascination réciproque (Paris: M. de Maule, 2007), 24. Cf. Karin Andersson, "Selma Lagerlöf en France", in La Nord à la lumière du Sud: Mélanges offerts à Jean-François Battail, Deshima: Revue d'histoire globale des pays du Nord, 3, ed. Sylvain Briens and Martin Kylhammar (Strasbourg: Départements d'études néerlandaises et scandinaves, Université de Strasbourg, 20I3, I6I-I75.

${ }^{4}$ May-Britt Lehman, "Lettre recommandée, Stad $i$ ljus: heurs et malheurs de la publication d'un roman d'Eyvind Johnson" and Birgit Munkhammar, "Eyvind Johnsons franska debut", both in La Nord à la lumière du Sud: Mélanges offerts à Jean-François Battail, Deshima: Revue d'histoire globale des pays du Nord, 3, ed. Sylvain Briens and Martin Kylhammar (Strasbourg: Départements d'études néerlandaises et scandinaves, Université de Strasbourg), 2013, I77-204/205-I9.

5 Cf. Karin Dahl, La Mythification d'un écrivain étranger. La réception de l'œuvre de Stig Dagerman en France et en Italie (Göteborg: Avdelningen för franska och italienska, Göteborgs universitet, 2008).

${ }^{6}$ The main source for bibliographical data will be Dennis Ballu's Lettres nordiques. Une bibliographie I720-20I3 (Stockholm: Kungl. biblioteket, 20I6). 
the concept of world literature and the introduction of a number of factors contributing to the circulation of literary works outside their original context. Some preliminary conclusions, based on earlier bibliographical research, will also be drawn. ${ }^{7}$

\section{A Circulational Approach to the Concept of World Literature}

My understanding of the concept of "world literature" is a circulational one. ${ }^{8}$ The study of world literature, I contend, is the study of all literature crossing borders, circulating outside its original context, no matter what kind of literature, in no matter what source language. This understanding has been popularised since the turn of the millennium by such scholars as Pascale Casanova (The World Republic of Letters [1999/2004]) and Franco Moretti (e.g. "Conjectures on World Literature" [2000]).

For Moretti, world literature is not a canon or a set of works it is not even an object, "it's a problem, and a problem that asks for a new critical method". ${ }^{9}$ If one accepts his view, world literature should be a new way to study literature as a border-crossing phenomenon and on a much larger scale than before. Moretti is chiefly interested in genres and the spread and development of genres throughout the world. Reading at a distance, he identifies configurations common to the literary development in several different cultures. He uses these pieces of evidence "to reflect on the

7 An earlier version of this essay has been published in Swedish. Cf. Andreas Hedberg, "Ett unikt kulturflöde. Den svenska litteraturens väg till Frankrike", in Médiations interculturelles entre la France et la Suède: Trajectoires et circulations de I945 à nos jours, edited by Sylvain Briens and Mickaëlle Cedergren (Stockholm: Stockholm University Press, 20I 5 ), p. III-I7.

8 Cf. Stefan Helgesson, "Going Global: An Afterword", in Literary History: Towards a Global Perspective, Vol. 4: Literary Interactions in the Modern World 2, ed. Stefan Helgesson (Berlin: W. de Gruyter), 303-2I.

9 Franco Moretti, "Conjectures on World Literature and More Conjectures" (2000/2003), in World Literature: A Reader, ed.Theo D’haen, César Dominguez and Mads Rosendahl Thomsen (London; New York: Routledge, 2013), I6I-62. 
relation between market and [literary] forms" in order to uncover what he terms "laws of literary evolution". ${ }^{\circ}$

Moretti's approach to world literature is true to Johann Wolfgang von Goethe's original statement on world literature, given in the poet's conversations with his personal secretary Johan Peter Eckermann: that national literature "means little now", that "the age of Weltiteratur has begun" and that "everyone should further its course". ${ }^{\text {II }}$ For Moretti too, national literatures mean little, because he considers them abstractly, as examples to be studied from a great distance. Goethe's stance has been called "idealistic" and "too optimistic", ${ }^{\mathrm{I} 2}$ but if we follow Moretti, the age of world literature might very well be upon us, at least in the field of literary scholarship. When studying peripheral literatures and their relation to the world republic of letters using Moretti's methods, one might be able to formulate general points that can be applicable to other cases of how a minor language literature is mediated to the world. ${ }^{\mathrm{I}}{ }^{3}$ This, however, is difficult to achieve without an operational understanding of the relationship between nation states and literature as an international phenomenon.

According to Casanova, there is, in the development of world literary space, a constant tendency towards autonomy, towards "literary emancipation in the face of political (and national) claims to authority". ${ }^{\mathrm{I} 4}$ But at the same time, literature suffers from an "original dependence" on the nation. Its medium, language, is "invariably appropriated by national authorities as a symbol

ז Moretti, "Conjectures on World Literature and More Conjectures”, I 63.

" Johann Wolfgang von Goethe, "On World Literature” (I 827), in World Literature: A Reader, ed. Theo D'haen, César Dominguez and Mads Rosendahl Thomsen (London; New York: Routledge, 20I3), I I.

I2 Mads Rosendahl Thomsen, Mapping World Literature: International Canonization and Transnational Literatures (London; New York: Continuum International Publishing Group, 2008), I I.

${ }^{2}$ Nevertheless, one should not forget that, as Casanova puts it, "not all those who are literarily dominated find themselves in the same situation" and that "each one is dependent in a specific way" (Pascale Casanova, The World Republic of Letters, trans. M. B. Debevoise [Cambridge MA; London: Harvard University Press, 2004], 83).

${ }^{14}$ Casanova, World Republic of Letters, 39. 
of identity", and literary resources are "inevitably concentrated [...] within the boundaries of the nation itself". ${ }^{\text {Is }}$ Consequently, Casanova, while insisting that the international literary space is relatively independent of the everyday world, that its boundaries does not completely coincide with those of the political or economic world, also criticises the naïve conception of literature as "pure", denationalised and dehistoricised. ${ }^{16}$

\section{Literature, Economy and Sweden}

Casanova's stance is an important theoretical starting point for the project at hand. To understand the logic at work in the transnational flows of literature, one needs to consider, among other things, the economic importance of the countries in which these languages are spoken. If we - for example - establish every language's share of the total Gross Domestic Product of the world, Swedish (whose relation to French is the main focus of this project) ends up high on the list. Sweden's economic power makes Swedish more than ten times more important than it should be, considering that Swedes only make up o.I 4 per cent of the world's population. ${ }^{17}$ Swedish publishers have the economic means to

${ }^{15}$ Casanova, World Republic of Letters, 34.

${ }^{16}$ Casanova, World Republic of Letters, 23. For a somewhat critical discussion of Casanova's view on the relation between literature and nation, see Alexander Beecroft, "World Literature without a Hyphen. Towards a Typology of Literary Systems”, in New Left Review, November-December 2008, eg. 97-98. Beecroft's criticism echoes Christopher Prendergast's in his review of Casanova's book (Christopher Prendergast, "Negotiating World Literature", in New Left Review, March-April 200I, IOO-2I). Prendergast is severe in his critique of what he calls Casanova's "national-competitive model", claiming that it dangerously simplifies her account of literary history (I09). He also points to weaknesses in Casanova's "ethnocentric" and print-centred definition of "literature" ( I I 8-19).

${ }^{17}$ Johan Svedjedal, "Svensk skönlitteratur i världen: Litteratursociologiska problem och perspektiv", in Svensk litteratur som världslitteratur: En antologi, Skrifter utgivna av Avdelningen för litteratursociologi vid Litteraturvetenskapliga institutionen i Uppsala, 65, edited by Johan Svedjedal (Uppsala: Avdelningen för litteratursociologi, Uppsala universitet, 20I2), 28. 
advertise their products abroad. Also, the Swedish state has the means to create and uphold institutions such as the Swedish Institute, advertising Sweden and Swedish culture abroad and financing the teaching of Swedish around the world. The Swedish Arts Council, also financed by the Swedish state, makes important economic contributions to the translation of Swedish fiction. ${ }^{18}$

These facts are not to be forgotten when studying the cultural relationships between Sweden and France. Statistics from The Swedish Arts Council show that French publishers and translators are very active when it comes to applying for translation grants (I7 applications in 20I2, making France number five on the list of countries with the most applications). Furthermore, according to statistics from the Swedish Institute, France is the fifth country in the world when it comes to the number of university students studying Swedish (approximately 800 students in 201 5 ). Teaching is partly financed by the Swedish Institute, which spends more money per student in France than in any other country, except for Russia and Poland. These, of course, are factors that contribute to patterns in the mediation of Swedish literature to the French book market.

\section{Paris: The Capital of the Literary World}

As Casanova has suggested, world literature should be studied as a separate literary field, with mechanisms of consecration similar to those at play in the national literary fields. This means that we have to consider not only economic factors, but also factors unique for the literary or cultural fields, such as the reversed economy, as understood by Casanova's teacher Pierre Bourdieu, and strong ideas about literary centres and peripheries. Such an idea is Casanova's of Paris as "the capital of the literary world", which means that a writer who wants to be part of world literature must

${ }^{18}$ For a comprehensive history of state support for Swedish literature abroad, cf. Agnes Broomé, Swedish Literature on the British Market I998-20 I3: A Systemic Approach (London: Department of Scandinavian Studies, UCL, 20I 5), 2I3-32. 
be consecrated in the literary milieu of the French capital. ${ }^{19}$ This hypothesis has been called into question ${ }^{20}$ - especially following the rise of other literary centres, such as London and New York but no matter if Casanova is right or wrong, the idea, or perception, of Paris as a centre, is sufficiently strong and widespread to influence the literary world in tangible ways. As Casanova herself puts it: a literary centre exists "both in the imaginations of those who inhabit it [and, one might add, those who inhabit the entire world republic of letters] and in the reality of the measurable effects it produces". ${ }^{21}$ The recitation of the glories of Paris, "by virtue of being repeated as something obvious, gradually comes to acquire a reality of its own". ${ }^{22}$

For example, writers from minor languages, such as Sweden's August Strindberg, have gone to great pains in order to have their work translated into French. ${ }^{23}$ (Strindberg's contemporary, the Danish literary scholar Georg Brandes contended - much like Casanova - that " $[\mathrm{w}]$ hen an author is acknowledged in France, he is known across the entire earth". ${ }^{24}$ Efforts like Strindberg's, and of other writers from what literary sociologist Robert Escarpit has

19 Casanova, World Republic of Letters, 24, I 27.

${ }^{20}$ Alexander Beecroft, for example, suggests that Casanova's model has "the perhaps unintended effect of re-inscribing a hegemonic cultural centre", even though her "avowed desire is to globalize literary studies" (Beecroft, "World Literature without a Hyphen. Towards a Typology of Literary Systems", 88). Beecroft also points to the limited scope of Casanova's (and Moretti's) theories: "If we wish our model of the world to extend deeply into the past, then [these theories], useful as they are in their own context, will not suffice" (9I). Furthermore, he claims that Casanova's model is too focused on the national literatures, which makes it "inadequate", since "a number of languages and their literatures transcend national borders and because the de-centring of the nation state brought about by contemporary global capitalism alters literary circulation" (98).

${ }_{21}$ Casanova, World Republic of Letters, 24.

22 Casanova, World Republic of Letters, 26.

23 Concerning Strindberg's attempt to "conquer Paris", cf. Casanova, World Republic of Letters, I37-I 38 .

${ }^{24}$ Georg Brandes, "World Literature" (I899), in World Literature: A Reader, edited by Theo D'haen, César Dominguez and Mads Rosendahl Thomsen (London; New York: Routledge, 2013), 25. 
called "le circuit lettré", ${ }^{25}$ have meant that canonised literature makes up a larger share of the fiction translated from Swedish to French than of fiction translated from Swedish to many other languages.

Looking closer at the translation of Swedish fiction into French, it is possible to collect statistical data that tests Casanova's suppositions about France's unique position in the literary world. For example, one might consider the translations of children's books. Statistically, children's books make up an impressive share of all fiction translated from Swedish: about 60 per cent. But the proportion varies between the different target languages. Among the translations to English, the share of children's books is close to the average, with 57 per cent. For translations to Japanese, it is as high as 84 per cent. But - coming back to Casanova - for translations to French, it is only 39 per cent. ${ }^{26}$ The popular Swedish children's book author Astrid Lindgren, whose dominance is overwhelming in almost every target language, is in French surpassed by both the Nobel prize laureate Selma Lagerlöf and August Strindberg. ${ }^{27}$ Similarly, still active writers who can be considered part of Sweden's literary canon - "le circuit lettré"- are comparatively widespread in France. These facts can be partly explained with reference to France's reputation as a major literary power. Canonised writers have made active efforts to have their work translated into French, in the belief that if they take Paris first, they can then move on to take the world.

${ }_{25}$ Robert Escarpit, Sociologie de la littérature, Que sais-je?, 777, 8 ed. (Paris: Presse Universitaire de France, I992 [1958]).

${ }_{26}$ Andreas Hedberg, "Språk, genrer, författare. Sökningar i Kungl. bibliotekets bibliografi Suecana Extranea", in Svensk litteratur som världslitteratur: En antologi, Skrifter utgivna av Avdelningen för litteratursociologi vid Litteraturvetenskapliga institutionen i Uppsala, 65, ed. Johan Svedjedal, (Uppsala: Avdelningen för litterartursociologi, Uppsala universitet, 20I 2), I 2 I-22.

27 Ballu, Lettres nordiques I720-2013,913. 


\section{The Changing Itineraries of World Literary Space}

Translations to certain languages - like French - seem to be particularly important for continued distribution and translation of literary works written in minor languages. These transit languages play integral parts in the global network of literature. Much like people, books tend to follow established routes from one country to another; a translation into one language often means a translation into another. In the case of fiction translated from Swedish, German - by far the most important of the Germanic languages - has played an essential role as a transit language. ${ }^{28}$

However, the itineraries of literature are changing rapidly. Today, books can find new routes, and their journey into the world is much quicker. Of course, many factors contribute to this remarkable development, of which several have been discussed by the Danish literary sociologist Hans Hertel, who speaks of concentration (a direct consequence of the conglomerisation of the media market; whereby the large-scale economics of the modern book industry force publishers to merge into larger units in order to survive ever harsher competition) and polarisation (a growing gap on the book market, between big and small publishers, between big and small book shops and chain stores and between bestsellers and failed titles) as two dominant trends of the modern book market. ${ }^{29}$ Large-scale economics and media conglomerates contribute to a fast-paced bestseller culture, dominated by enormous book fairs and a system of literary agents, where Swedish publishing houses have made pioneering

${ }^{28}$ Lars Lönnroth, "Den svenska litteraturen på världsmarknaden”, in Den svenska litteraturen, 7: Bokmarknad, bibliografier, samlingsregister (Stockholm: Bonnier, I990), 38.

29 Hans Hertel, "Boken i mediesymbiosens tid", in Litteratursociologi: Texter om litteratur och sambälle, edited by Lars Furuland and Johan Svedjedal, 2 ed. (Lund: Studentlitteratur, 20I2), 225. For a critical discussion of Hertel's points, cf. Andreas Hedberg, "Small Actors, Important Task: Independent Publishers and their Importance for the Transmission of French and Romance Language Fiction to Sweden Since the Turn of the Millennium”, in Moderna Språk I Io, no. 2 (20I 6): 2I-30. 
contributions..$^{30}$ This development of the modern book market has meant considerable changes in the mediation of Swedish fiction to the international market, not only when it comes to pace and itineraries, but also when it comes to selection.

As a consequence of the phenomena studied by Hertel, Swedish fiction now has a different face or image in the eyes of the world. In the I960s, while Astrid Lindgren unquestionably was the most translated of all Swedish writers, there was still quite a large share of canonised authors on the "top list". But today, the situation is completely different. Canonised literature has disappeared, replaced by crime fiction, which, together with the always popular children's books, make up Sweden's contribution to world literature. ${ }^{3}{ }^{\mathrm{I}}$ Effects of this development are clearly visible also on the French book market. The significant rise of the number of Swedish novels published in French translation since the turn of

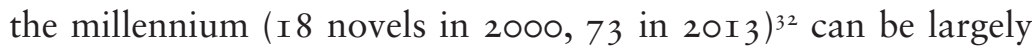
explained with reference to the so called "boom" of Scandinavian crime fiction. In 20I3, Swedish was the fifth most important source language for translated novels published in France (after English, German, Spanish and Italian). ${ }^{33}$ These patterns will be further examined in the project at hand.

In keeping with the theoretical framework and research principles outlined in this introductory essay - such as the focus on e.g. translation grants, Scandinavian studies and the role of literary mediators - the research project "From Periphery to Center" will discuss translations of Swedish fiction published on the French book market since the second world war. Translation flows will be followed through time, developments traced and highs and lows identified and explained. Also, the importance of specific genres will be studied, e.g. children's books, poetry and crime fiction.

${ }^{\circ}$ Karl Berglund, "A Turn to the Rights. The Advent and Impact of Swedish Literary Agents", in Hype. Bestsellers and Literary Culture, edited by Jon Helgason, Sara Kärrholm and Ann Steiner (Lund: Nordic Academic Press, 20I4), 67-87.

31 Svedjedal, "Svensk skönlitteratur i världen: Litteratursociologiska problem och perspektiv", 49-5I.

32 Ballu, Lettres nordiques I720-20I3, 9I6-I7.

33 Ballu, Lettres nordiques I720-20I3, 9I 2-I3. 
Finally, a study of a small number of translated works will aim at a description of how Swedish fiction is mediated to the French readers, using, for example, Lawrence Venuti's distinction between foreignisation and domestication. ${ }^{34}$ Already, one might point to some interesting characteristics of Sweden and France as literary spheres; Swedish literature, fuelled by for example a strong economy and strong institutions, seems more semi-peripheral than peripheral while France - as a result of a traditional and still important belief in Paris as a literary center - comes across as an important transit market and generator of literary value.

A study of this kind - in which literature is regarded as a travelling phenomenon - seems true to Goethe's idealistic stance on literature. In the wake of nationalist movements in today's Europe, this seems an important undertaking. Interestingly, Goethe, in his conversations with Eckermann, leaves room for hesitation. He calls upon us to "further [the] course" of world literature, as if this is something that needs to be done. This combination of optimism and concern is mirrored in Casanova's The World Republic of Letters, where the formation of a world literary space is described as a constant struggle between "the centripetal forces that strengthen the autonomous and unifying pole" of literature and "the centrifugal forces associated with the national poles of each national space". ${ }^{35}$ Closed borders, Casanova suggests, never meant anything good for literature; instead, they bring literary development to a staggering halt. National literatures bring stylistic conservatism; international culture, on the other hand, brings literary innovation..$^{6}$ The study of literature as an international phenomenon, especially when guided by a circulational approach to the concept of world literature, may very well strengthen the centripetal forces of world literary space.

34 Lawrence Venuti, The Translator's Invisibility. A History of Translation (London; New York: Routledge, I995), 20.

35 Casanova, World Republic of Letters, I09.

${ }^{6}$ Casanova, World Republic of Letters, I 2. 


\section{Bibliography}

Andersson, Karin. "Selma Lagerlöf en France”. In La Nord à la lumière du Sud. Mélanges offerts à Jean-François Battail, Deshima. Revue d'histoire globale des pays du Nord, 3, edited by Sylvain Briens and Martin Kylhammar, I6I-75. Strasbourg: Départements d'études néerlandaises et scandinaves, Université de Strasbourg, 20I3.

Ballu, Dennis. Lettres nordiques. Une bibliographie I720-20I3. Stockholm: Kungl. biblioteket, 2016.

Battail, Marianne and Jean-François Battail, eds. Une Amitié millénaire: Les relations entre la France et la Suède à travers les ages, L'historie dans l'actualité, Paris: Beauchesne, I 993.

Beecroft, Alexander. "World Literature without a Hyphen: Towards a Typology of Literary Systems". In New Left Review (NovemberDecember 2008), 87-100.

Berglund, Karl. "A Turn to the Rights. The Advent and Impact of Swedish Literary Agents". In Hype: Bestsellers and Literary Culture, edited by Jon Helgason, Sara Kärrholm and Ann Steiner, 67-87. Lund: Nordic Academic Press, 20I4.

Brandes, Georg. "World Literature” (I 899). In World Literature: A Reader, edited by Theo D'haen, César Dominguez and Mads Rosendahl Thomsen, 23-27. London; New York: Routledge, 20I3.

Briens, Sylvain and Martin Kylhammar. Poétocratie. Les écrivains à l'avant-garde du modèle suédois. Paris: Ithaque, 2016.

Broomé, Agnes. Swedish Literature on the British Market I99820I3: A Systemic Approach. London: Department of Scandinavian Studies, UCL, 2015 .

Casanova, Pascal. The World Republic of Letters. Translated by M. B. Debevoise. Cambridge MA: Harvard University Press, 2004 [I999].

Dahl, Karin. La Mythification d'un écrivain étranger. La réception de l'œuvre de Stig Dagerman en France et en Italie. Göteborg: Avdelningen för franska och italienska, Göteborgs universitet, 2008. 
Escarpit, Robert. Sociologie de la littérature, Que sais-je? 777, 8 ed. Paris: Presse Universitaire de France, I992 [I958].

Faramond, Guy de. Svea \& Marianne. Les relations franco-suédoises, une fascination réciproque. Paris: M. de Maule, 2007.

Goethe, Johann Wolfang (von). "On World Literature" (I 827). In World Literature: A Reader, edited by Theo D'haen, César Dominguez and Mads Rosendahl Thomsen, 9-I5. New York: Routledge, 20I3.

Hedberg, Andreas. "Språk, genrer, författare. Sökningar i Kungl. bibliotekets bibliografi Suecana Extranea". In Svensk litteratur som världslitteratur: En antologi, Skrifter utgivna av Avdelningen för litteratursociologi vid Litteraturvetenskapliga institutionen i Uppsala, 65, edited by Johan Svedjedal, II7-34. Uppsala: Avdelningen för litteratursociologi, Uppsala universitet, $20 \mathrm{I} 2$.

—_. "Ett unikt kulturflöde. Den svenska litteraturens väg till Frankrike". In Médiations interculturelles entre la France et la Suède: Trajectoires et circulations de I945 à nos jours, edited by Sylvain Briens and Mickaëlle Cedergren, III-I7. Stockholm: Stockholm University Press, 2015.

. "Small Actors, Important Task: Independent Publishers and their Importance for the Transmission of French and Romance Language Fiction to Sweden Since the Turn of the Millennium". Moderna Språk I Io, no. 2 (20I6): 2 I-30.

Helgesson, Stefan. “Going Global: An Afterword”. In Literary History: Towards a Global Perspective, Vol. 4: Literary Interactions in the Modern World 2, edited by Stefan Helgesson, 303-2I. Berlin: W. de Gruyter, 2006.

Hertel, Hans. "Boken i mediesymbiosens tid". In Litteratursociologi: Texter om litteratur och sambälle, edited by Lars Furuland and Johan Svedjedal, 2 ed., 22 I-42. Lund: Studentlitteratur, 2012.

Lehman, May-Britt. "Lettre recommandée, Stad i ljus: heurs et malheurs de la publication d'un roman d'Eyvind Johnson". In La Nord à la lumière du Sud. Mélanges offerts à Jean-François Battail, Deshima. Revue d'histoire globale des pays du Nord, 3, edited by 
Sylvain Briens and Martin Kylhammar, I77-204. Strasbourg:

Départements d'études néerlandaises et scandinaves, Université de Strasbourg, 20I3.

Lönnroth, Lars. "Den svenska litteraturen på världsmarknaden”. In Den svenska litteraturen, 7: Bokmarknad, bibliografier, samlingsregister, 38-43. Stockholm: Bonnier, I990.

Moretti, Franco. "Conjectures on World Literature and More Conjectures" (2000/2003). In World Literature: A Reader, edited by Theo D'haen, César Dominguez and Mads Rosendahl Thomsen, I60-75. London; New York: Routledge, 20I3.

Munkhammar, Birgit. "Eyvind Johnsons franska debut”. In La Nord à la lumière du Sud. Mélanges offerts à Jean-François Battail, Deshima. Revue d'histoire globale des pays du Nord, 3, edited by Sylvain Briens and Martin Kylhammar, 205-I9. Strasbourg: Départements d'études néerlandaises et scandinaves, Université de Strasbourg, 2013.

Prendergast, Christopher. "Negotiating World Literature”. New Left Review (March-April 200I), I00-2I.

Svedjedal, Johan. “Svenskskönlitteraturivärlden:Litteratursociologiska problem och perspektiv”. In Svensk litteratur som världslitteratur: En antologi, Skrifter utgivna av Avdelningen för litteratursociologi vid Litteraturvetenskapliga institutionen i Uppsala, 65, edited by Johan Svedjedal, 9-82. Uppsala: Avdelningen för litteratursociologi, Uppsala universitet, 20 I 2.

Thomsen, Mads Rosendahl. Mapping World Literature: International Canonization and Transnational Literatures. London: Continuum, 2008.

Venuti, Lawrence. The Translator's Invisibility: A History of Translation, London; New York: Routledge, I995. 